\title{
A multidisciplinary approach for external cervical resorption: A case report with 5-
}

\section{year follow-up}

\author{
Uma abordagem multidisciplinar para reabsorção cervical externa: Um relato de caso com \\ acompanhamento de 5 anos \\ Un enfoque multidisciplinario para la reabsorción cervical externa: Reporte de un caso con \\ seguimiento de 5 años
}

Laryssa de Castro Oliveira

ORCID: https://orcid.org/0000-0001-7689-4969

São Paulo State University, Brazil

E-mail: laryssa.castro@unesp.br

Diego Felipe Mardegan Gonçalves ORCID: https://orcid.org/0000-0002-3885-9000

São Paulo State University, Brazil

E-mail: mardegan.goncalves@unesp.br

Fernanda de Souza e Silva Ramos

ORCID: https://orcid.org/0000-0003-2222-2424

São Paulo State University, Brazil

E-mail: fer_ramos_fer@hotmail.com

Gabriel Valagna Mauro

ORCID: https://orcid.org/0000-0002-3889-0913

Adamantina School of Dentistry, Brazil

E-mail: gabrielvalagnamuro@hotmail.com

Silvio José Mauro

ORCID: https://orcid.org/0000-0003-4927-6473

São Paulo State University, Brazil

E-mail: silvio.jose@unesp.br

Sandra Rahal Mestrener

ORCID: https://orcid.org/0000-0003-3359-6982

São Paulo State University, Brazil

E-mail: sandrarahal11@gmail.com

Ticiane Cestari Fagundes

ORCID: https://orcid.org/0000-0002-3418-0498

São Paulo State University, Brazil

E-mail: ticiane.fagundes@unesp.br

\begin{abstract}
Introduction: External cervical resorption (ECR) is a physiological or pathological event usually detected on radiographic examination, since there are no symptoms in its initial and intermediate phases. Objectives: This case is an important finding because the early detection of this lesion allowed an effective multidisciplinary approach to be carried out. Case Report: Radiography was taken in a 55-year-old male and revealed a radiolucent area on the distal surface of the permanent mandibular left first molar, suggesting ECR with impaired pulpal vitality. Based on the clinical and radiographic examinations, a multidisciplinary approach was established involving endodontic treatment, periodontal surgery and indirect restoration that provided an option for preserve the affected tooth. The early diagnosis of ECR was essential for the successful treatment in order to maintain the satisfactory function for five-year follow-up. Conclusion: Despite the procedures performed, the idiopathic etiology of the lesion contributed to the appearance of recurrences; however, monitoring and maintenance of the affected tooth proved to be important for the longevity of the treatment.
\end{abstract}

Keywords: Case reports; Oral diagnosis; Periodontal ligament; Root canal obturation; Tooth resorption.

\section{Resumo}

Introdução: A reabsorção cervical externa (RCE) é um evento fisiológico ou patológico geralmente detectado no exame radiográfico, uma vez que não apresenta sintomas em suas fases inicial e intermediária. Objetivo: Este caso é um achado importante porque a detecção precoce desta lesão permitiu uma abordagem multidisciplinar eficaz por um longo período de tempo. Relato de Caso: A radiografia foi feita em um homem de 55 anos e revelou uma área radiolúcida na superfície distal do primeiro molar permanente inferior esquerdo, sugerindo um RCE com vitalidade pulpar prejudicada. Com 
base em exames clínicos e radiográficos, foi estabelecida uma abordagem multidisciplinar que envolveu tratamento endodôntico, cirurgia periodontal e restauração indireta que forneceu uma opção para preservar o dente afetado. $\mathrm{O}$ diagnóstico precoce de RCE foi essencial para o sucesso do tratamento, a fim de manter a função do dente ao longo de um acompanhamento de cinco anos. Conclusão: Apesar dos procedimentos realizados, a etiologia idiopática da lesão contribuiu para o aparecimento de recividas; no entanto, o acompanhamento e a manutenção do dente afetado mostraram-se importantes para a longevidade do tratamento.

Palavras-chave: Relatos de casos; Diagnóstico bucal; Ligamento periodontal; Obturação do canal radicular; Reabsorção do dente.

\section{Resumen}

Introducción: La reabsorción cervical externa (ECR) es un evento fisiológico o patológico que generalmente se detecta en el examen radiográfico, ya que no presenta síntomas en sus fases inicial e intermedia. Objetivos: Este caso es un hallazgo importante porque la detección precoz de esta lesión permitió realizar un abordaje multidisciplinar eficaz. Caso clínico: La radiografía se tomó en un varón de 55 años y reveló el área radiotransparente en la superficie distal del primer molar inferior izquierdo permanente, sugiriendo una ECR con vitalidad pulpar deteriorada. Con base en los exámenes clínicos y radiográficos, se estableció un abordaje multidisciplinario que involucró tratamiento endodóntico, cirugía periodontal y restauración indirecta que brindó una opción para preservar el diente afectado. El diagnóstico temprano de RCE fue esencial para un tratamiento exitoso con el fin de mantener la función dental durante un seguimiento de cinco años. Conclusión: A pesar de los procedimientos realizados, la etiología idiopática de la lesión contribuyó a la aparición de recidivas; sin embargo, el seguimiento y mantenimiento del diente afectado resultó ser importante para la longevidad del tratamiento.

Palabras clave: Informes de casos; Diagnóstico bucal; Ligamento periodontal; Obturación del conducto radicular; Resorción dental.

\section{Introduction}

Dental resorption can be classified as internal or external and according to the Andreasen Classification, which is the most frequently cited in the literature for classifying resorption through its location, type and presence or absence of trauma, external cervical resorption (ECR) can be further categorized as inflammatory, replacement, and surface resorption (Aidos, Diogo \& Santos, 2018; Patel, Lambrechts, Shemesh \& Mavridou, 2018b; Mavridou, et al., 2016) and characterized by progressive loss of dentin through the continued action of osteoclast cells with the invasion of the cervical region by fibro vascular tissue (Chen, Huang \& Deng, 2021a; Patel et al., 2018b; Patel, Mavridou, Lambrechts \& Saberi, 2018c) The damage of cementum exposes the root surface to the osteoclasts, which then causes dentin resorption (Patel et al., 2018c). Clinically, usually presents asymptomatic because as ECR proceeds, resorptive tissues extend circumferentially or horizontally in the dentin while leaving the pulp intact. (Gijón, Martín, Encinas \& Navajas, 2016; Ahmed, Gopalakrishnan \& Parthasarthy, 2014).

Nevertheless, the etiology of ECR is still poorly understood, which adds to the difficulty in early diagnosis and advanced cases may extend coronally or apically and present with mottled appearance caused by the bony nature of the lesion (Chen, Huang \& Deng, 2021b; Gijón et al., 2016). The differential diagnosis will determine the treatment because this resorption can be difficult to identify on a periapical radiograph, since there is no 'classic' radiographic appearance and the lesions may be radiolucent, radiopaque or present as a combination of both depending on the stage of the lesion (Patel et al., 2018b; Mavridou, Bergmans, Barendreagt \& Lambrechts, 2017). In terms of potential predisposing factors, trauma and orthodontic treatment were recognized as the main risk factors, while periodontal surgery, restoration and bruxism were also identified as common risk factors. However, aetiological factors in ECR are those that favour the activation of clastic cells, opening the possibility for idiopathic etiology (Chen et al.,2021b; Mavridou et al., 2017).

ECR was used to be considered as a rare disease due to a lack of case reports and its prevalence rate varied from $0.02 \%$ to $0.08 \%$ (Chen et al.,2021a; Howait, Shaker, Aljuhani \& AlMohnna, 2021). However, in recent years it has received increasing attention due to the growing number of clinical cases, especially due to greater access by people to advanced means of diagnosis as digital radiography and the higher level of knowledge of this issue by the professionals, which leads to identifying more cases at their early stages (Consolaro, 2016; Sarmento et al., 2020; Sharma, Kumar, Jain \& Logani, 2019; Libonati, Montella, 
Montemurro \& Campanella, 2017; Marinescu, et al., 2019). Thus, in addition to the description of the case report, this article presents and discusses the importance of multidisciplinary planning, differential diagnosis and routine follow-up.

\section{Case Report}

Coronal darkening of the permanent mandibular left first molar was observed in a 55-year-old male (Figure 1A) at clinical routine clinical of UNESP - São Paulo State University, Araçatuba School of Dentistry. The patient did not report any injury that could have affected this tooth or systemic condition that could be a predisposing factor. A diffuse radiolucent area was observed, accompanied by thickening of the periodontal ligament in the radiograph (Figure 1B). The diagnosis of ECR was established based on these characteristics, concluding with idiopathic etiology. Before starting the initial photos and the treatment plan, the patient consented to the treatment and signed an authorization. Due to the absence of symptoms, lesion in periapical region and vitality test showing no vitality signs, the pulpectomy endodontic treatment was indicated (Figure 1C). Calcium hydroxide was used as a temporary therapeutic agent (Figure 1D).

Figure 1: Initial condition of the patient and the detection of ECR. A) Coronary darkening of permanent mandibular left first molar. B) Initial periapical radiograph showing a radiolucent lesion in the distal region, with well-defined limits. C) Dental element submitted to the pulp vitality test. D) Endodontic access and exposure of the root canals.
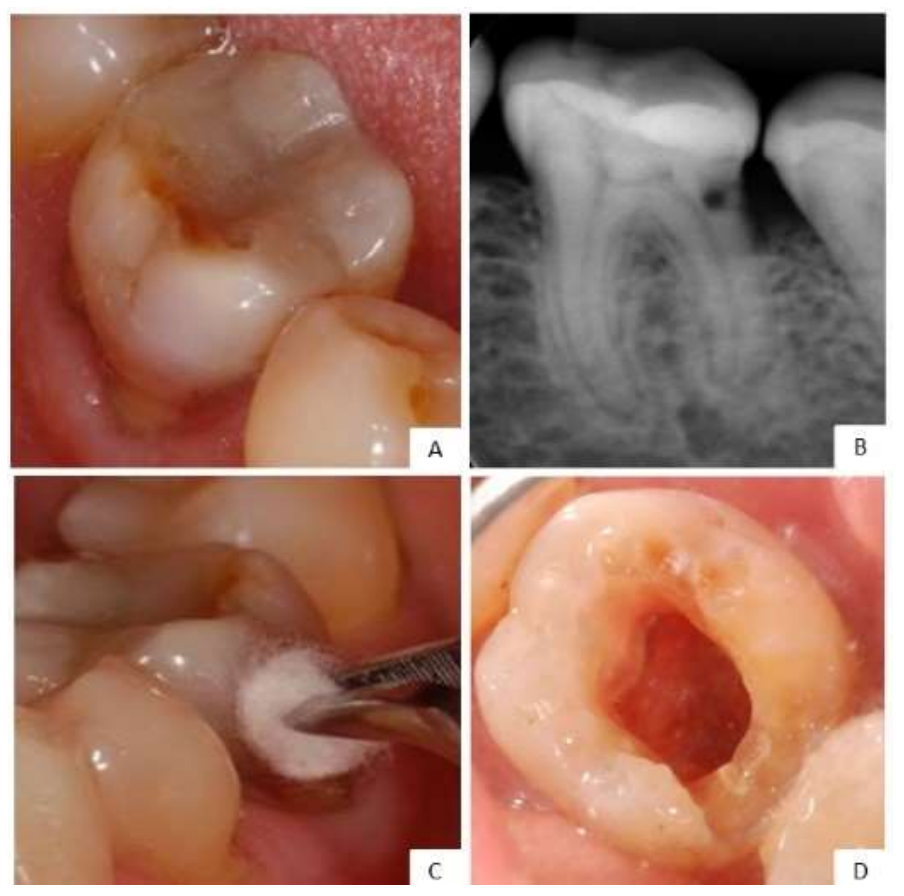

Source: Authors.

In the same session, a periodontal surgical therapy was performed by the reflection technique to expose the affected area and remove all granulation tissue (Figures 2A, 2B). To re-establish the biologic space, an osteotomy was performed in the distal region of the tooth. The flap was repositioned apically and the endodontic access was temporarily sealed (Figure $2 \mathrm{C}$ ). Twenty days later, the endodontic treatment was concluded and restoration with resin-modified glass ionomer cement and conventional composite resin was performed (Figure 2D). 
Figure 2: Surgical procedures for removing granulation tissue. A) Initial procedures of surgical therapy. B) Removal of all granulation tissue from the cavity. C) Temporary restoration after removal of the lesion. D) Twenty days post-operative after surgical therapy.
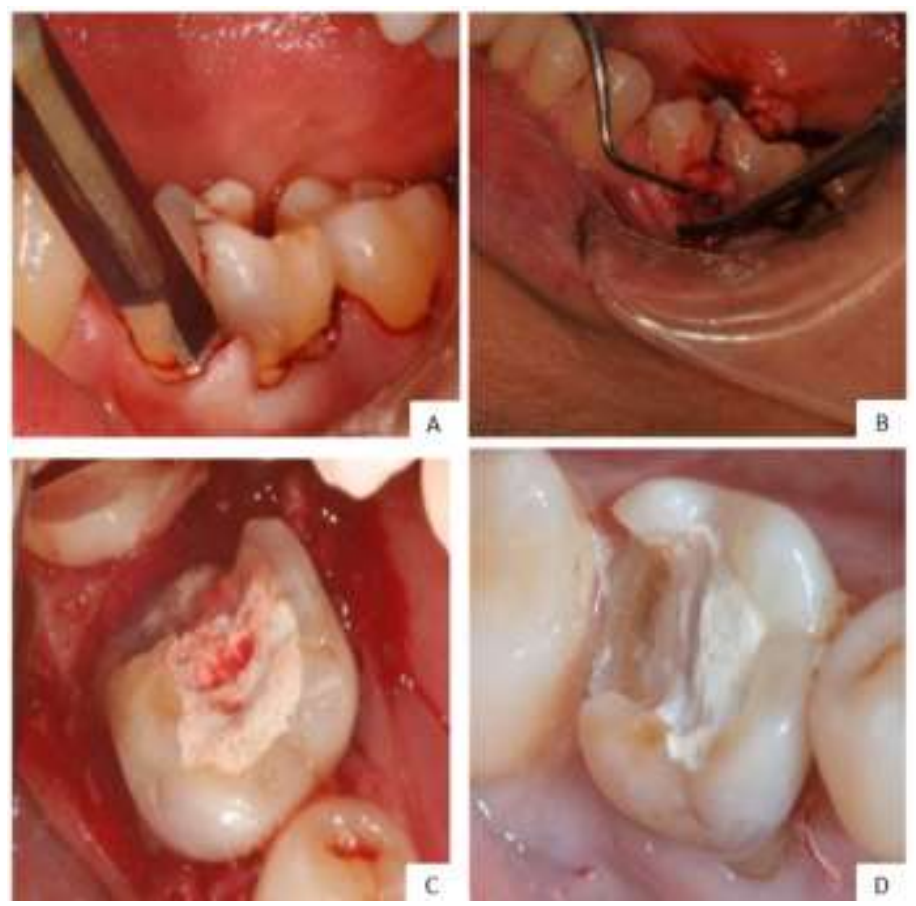

Source: Authors.

Then, a periapical radiograph was used to identify the cervical limits (Figure 3A), followed by preparation of the tooth and cementation of the provisional crown. In another session, the intraoral impressions were performed with irreversible hydrocolloid (Express, 3M ESPE, St. Paul, MN, USA). The metal-free crown was treated and an universal color self-adhesive resin cement (Relyx U200, 3M ESPE, St. Paul, MN, USA) was used to cement it (Figure 3B). A final periapical radiography was performed to verify the correct seating of the crown and follow-up was conducted until five years (Figures 3C, 3D). At the one-year follow-up, it was confirmed that the lesion was paralyzed. However, after this period, recurrence of the lesion was detected in the clinical and radiographic exams. 
Figure 3: Final stages of multidisciplinary case management. A) A periapical radiograph used to identify the cervical limits $f$ the preparation prior to cementation of the crown. B) Definitive crown cementation. C) Final periapical radiograph showing a periodontal condition without evidence of iatrogenesis. D) Radiograph after 5 years of follow-up, in which marked distal bone loss can be observed in a radiolucent area.

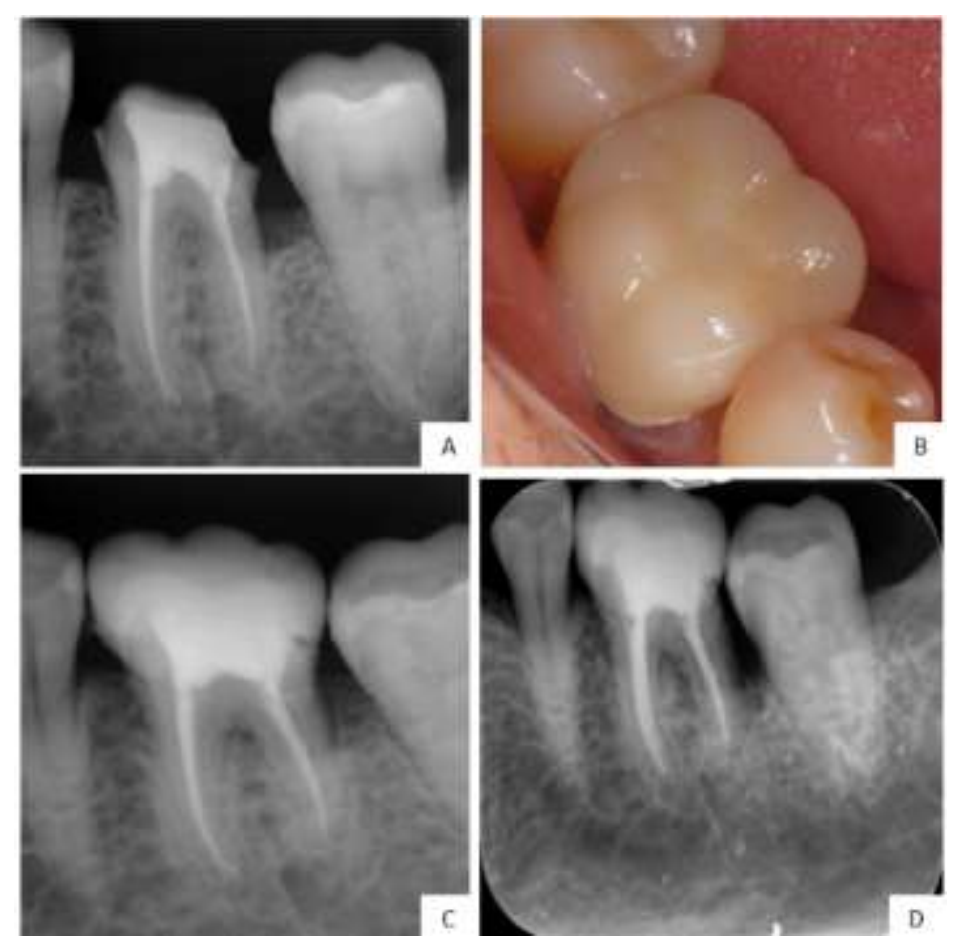

Source: Authors.

\section{Discussion}

The present case represents a multidisciplinary approach for ECR with etiology idiopatic. Therefore, differential diagnosis is necessary, because is usually diagnosed by radiographic finding (Mavridou et al., 2017; Ahmed et al., 2014; Marinescu, et al., 2019). When ECR presents with extensively cavitated cervical defects on the labial or lingual areas may be hard to distinguish it from root caries lesions. However, it is important to differentiate these lesions by probing because depending on its state, caries will feel soft or sticky, whereas ECR will be hard and scratchy producing a scraping sound when probed (Patel et al., 2018c; Sarmento et al., 2020; Ehlinger et al., 2019). The lesion location on the root surface directly interferes on treatment (Patel \& Beddis, 2019; Ehlinger et al., 2019; Libonati, et al., 2017). In advanced cases, a pink discoloration may appear on the tooth as a result of the soft tissue color shining through the thin tooth tissue overlying the resorption cavity (Patel, Foschi, Condon, Pimentel \& Bhuva, 2018a; Sarmento et al., 2020).

Moreover, many authors cited pre-available factors that contribute to occurrence of ECR process (Gijón et al., 2016; Ahmed et al., 2014; Patel et al., 2018a). In 2017, a study performed a descriptive analysis of potential predisposing factors based on 334 patients with ECR and conclude that sex did not seem to be a risk factor (Mavridou et al., 2017). A history of orthodontic therapy, trauma and poor oral health were the most associated factors (Chen et al., 2021b; Gijón et al., 2016) and others reported any that favour the activation of clastic cells, including biomechanical forces; mechanical, surgical and chemical trauma; endodontic microorganisms and their toxins; developmental defects; neoplasia; and hormonal disturbances (Chen et al., 2021a; Gijón et al., 2016; Patel et al., 2018a). The absence of all these factors and a radiographic examination contributed to the diagnosis of the present case as idiopathic etiology. In addition, 59\% of ECR cases were identified as multifactorial and, therefore, requiring a multidisciplinary treatment approach (Mavidrou et al., 2017). 
The management of ECR is dependent on the accessibility and the restorability of the lesion. It has been suggested two main treatment options: an external approach, requiring the surgical exposure of the resorption; and an internal approach, taking advantage of the endodontic access cavity (Sharma et al., 2019). Independently of the choice, the aim of the treatment is to completely remove the pathologic tissue and to seal the resulting defect without compromising tooth rehabilitation (Patel \& Beddis, 2019; Sharma et al., 2019; Libonati, et al., 2017). More invasive treatments are indicated when lesions are too severe, requiring extraction of the tooth (Kamat, Puranik, Vanaki \& Kamat, 2013).

Therefore, a periodontal, endodontic and restorative treatments has been established for the present case report. After removal of the granulation tissue, persistent bleeding is indicative of communicating from the periodontium extending into the cavity, hence the importance of removal of total granulomatous tissue with sharp excavators (Patel et al., 2018a). Once the ECR defect has been biological restored, the endodontic treatment may be performed. Smaller lesions have the most favorable outcome where typically the pulp is not involved, and in fact positive pulp sensibility testing is often found in teeth with ECR because the osteoclastic cells do not adhere to non-mineralized tissue (Consolaro, 2016; Patel et al., 2018c; Patel et al., 2018b). However, in this study, the tooth presented pulpal necrosis due to the communication of the ECR with the root canal and endodontic intervention was required and considering the coronal destruction, an indirect treatment was planned to restore the shape, function and esthetics of the tooth, thus ensuring greater longevity of the restorative procedure.

Thereby, clinical and radiographic monitoring in cases of ECR is fundamental for the success of the proposed therapy (Aidos et al., 2018; Ehlinger et al., 2019; Marinescu, et al., 2019; Aljarbou, 2019). In the present study, the bone loss in the treated area was observed in the 5-year follow-up with radiographic examination. ECR is a condition associated with physiological or pathological process that also results in the loss of bone (Sarmento et al., 2020). There is the possibility that mechanical forces could influence the bone loss and cause this new injury (Kamat et al., 2013). Another study also showed new injury after 7-years follow-up without any evident predisposing factor, and the treatment established was the extraction of the compromised tooth (Sharma et al., 2019). Using a follow-up, the result obtained in this case was satisfactory, as it allowed the tooth to remain in function for a long period of time. Despite this, the idiopathic etiological factor of the lesion allows for the possibility of several speculations about its recurrence.

\section{Final Considerations}

Early detection was essential for the planning and success of multidisciplinary treatment, promoting functionality to the patient for long periods of time. Despite this, long-term follow-up is essential, as there is a chance of recurrence when ROSC is idiopathic and further studies and case reports are needed so that professionals can propose better multidisciplinary treatment plans.

\section{Acknowledgments}

There are no sources of funding or financial support related to this study.

\section{References}

Ahmed N., Gopalakrishnan M. B. \& Parthasarthy H. (2014). External cervical resorption case report and a brief review of literature. Journal of Natural Science, Biology and Medicine, 5(1), 210-214. 10.4103/0976-9668.127336.

Aidos H., Diogo P. \& Santos J. M. (2018). Root resorption classifications: a narrative review and a clinical aid proposal for routine assessment. European Endodontic Journal, 3(3), 134-145. 10.14744/eej.2018.33043

Aljarbou F. A. (2019). Five-year recall after treatment of external cervical resorption. Case Reports in Dentistry, 19, 4957408. 10.1155/2019/4957408.

Chen Y., Huang Y. \& Deng X. (2021a). A review of external cervical resorption. Journal of Endodontics, 47(6), 883-894. 10.1016/j.joen.2021.03.004 
Research, Society and Development, v. 10, n. 9, e35310918029, 2021

(CC BY 4.0) | ISSN 2525-3409 | DOI: http://dx.doi.org/10.33448/rsd-v10i9.18029

Chen Y., Huang Y. \& Deng X. (2021b). External cervical resorption-a review of pathogenesis and potential predisposing factors. International Journal of Oral Science, 13(1), 19. 10.1038/s41368-021-00121-9

Consolaro A. (2016). External cervical resorption: diagnostic and treatment tips. Dental Press Journal of Orthodontics, 21(5), 19-25. 10.1590/21776709.21.5.019-025.oin.

Ehlinger C., Ginies E., Bornert F., Bahi-Gross S., Schmittbuhl M. \& Minoux M. (2019). Decision criteria influencing the therapeutic approach to invasive cervical resorption: a case series. Quintessence International, 50(6), 494-502. 10.3290/j.qi.a42479

Gijón V. R., Martín C. L., Encinas R. M. P. \& Navajas J. M. (2016). Aetiological, histopathological, clinical, diagnostic and therapeutical features of idiopathic cervical resorption. Dental Update, 43(10), 964-970. 10.12968/denu.2016.43.10.964

Howait M., Shaker M., Aljuhani H. \& AlMohnna M. (2021). External cervical resorption: a case report and brief review of the literature, and treatment algorithms. Journal of Contemporary Dental Practice, 22(3), 298-303. Retrieved from https://pubmed.ncbi.nlm.nih.gov/34210932/

Kamat M., Puranik R., Vanaki S. \& Kamat S. (2013). An insight into the regulatory mechanisms of cells involved in resorption of dental hard tissues. Journal of Oral and Maxillofacial Pathology, 17(2), 228-233. 10.4103/0973-029X.119736.

Libonati A., Montella D., Montemurro E. \& Campanella V. (2017). External cervical resorption: a case report. European Journal of Paediatric Dentistry, 18(4), 296-298. 10.23804/ejpd.2017.18.04.06

Marinescu I. R., Bănică A. C., Mercuţ V., Gheorghe A. G., Drăghici E. C., Cojocaru M. O., Scrieciu M. \& Popescu S. M. (2019). Root resorption diagnostic: role of digital panoramic radiography. Current Health Sciences Journal, 45(2), 156-166. 10.12865/CHSJ.45.02.05

Mavridou A. M., Bergmans L., Barendregt D. \& Lambrechts P. (2017) Descriptive Analysis of Factors Associated with External Cervical Resorption. Journal of Endodontics; 43(10):1602-1610.

Mavridou A. M., Hauben E., Wevers M., Schepers E., Bergmans L. \& Lambrechts P. (2016). Understanding external cervical resorption in vital teeth. Journal of Endodontics, 42(12), 1737-1751. 10.1016/j.joen.2016.06.007.

Patel J. \& Beddis H. P. (2019). How to assess and manage external cervical resorption. Brazilian Dental Journal, 227(8), 695-701. 10.1038/s41415-019-0781$\mathrm{x}$

Patel S., Foschi F., Condon R., Pimentel T. \& Bhuva B. (2018a). External cervical resorption: part 2 - management. International Endodontic Journal, 51(11), 1224-1238. 10.1111/iej.12946.

Patel S., Lambrechts P., Shemesh H. \& Mavridou, A. (2018b). European society of endodontology position statement: external cervical resorption. International Endodontic Journal, 51(12), 1323-1326. 10.1111/iej.13008

Patel S., Mavridou A. M., Lambrechts P. \& Saberi, N. (2018c). External cervical resorption-part 1: histopathology, distribution and presentation. International Endodontic Journal, 51(11), 1205-1223. 10.1111/iej.12942

Sarmento E. B., Tavares S. J., Thuller K. A., Falcao N. P., de Paula K. M., Antunes L. A., Gomes C. C. (2020). Minimally invasive intervention in external cervical resorption: a case report with six-year follow-up. International Journal of Burns and Trauma, 15(6), 324-330. https://pubmed.ncbi.nlm.nih.gov/33500844/

Sharma S., Kumar P., Jain V. \& Logani A. (2019). Multiple idiopathic cervical root resorption: diagnosis, clinical/radiographical/histological presentation, and rehabilitation - a 7-year follow-up case report. Journal of Conservative Dentistry, 22(3), 313-317. 10.4103/JCD.JCD_445_18 